\title{
HAS COVID-19 INFLUENCED ON TICK-BORNE DISEASES EPIDEMIOLOGY?
}

\section{CZY COVID-19 PRZYĆMIŁ CHOROBY ODKLESZCZOWE?}

\author{
Medical University in Białystok, Department of Infectious Diseases and Neuroinfections \\ Uniwersytet Medyczny w Białymstoku, Klinika Chorób Zakaźnych i Neuroinfekcji
}

For years tick-borne diseases have been an importatnt epidemiologial and clinical problem. The most frequent and best known are :Lyme disease (LD) and tick-borne encephalitis (TBE).

Yearly number of TBE cases in Europe for a long time has been at the level of $3000-4000$ cases: 2006 - 3776, 2009-3513, 2010-4049, 2019 - 4049, while in Poland 200-300 cases/ yera have been reported.

Similarly LD incidence in Western Europe is estimated to be $22.05 / 100,000$ a year. ${ }^{[26]} 2$ The total numer of cases (reported and not reported) might reach over 200,000 cases a year. ${ }^{[41]} .^{3}$ In Poland for the last few years ca 20,000 cases/year of LD have been reported.

With COVID 19 pandemics the structure of polish health care has changed with infectious diseases wards being transformed into COVID 19-only wards. This rised question whether current situation had influenced on the reported incidendce of tick-borne diseases including LD and TBE.

According to NIH in 201920630 cases of LD was reported in Poland (incidence - 53.74/100,000), including 294 cases of neuroborreliosis $(0.77 / 100,000)$, while in 2020 - 12524 cases of LD were reported, including 104 cases of neuroborreliosis $(0.27 / 100,000)$.

Similar tendency was observed as far as TBE incidence is concerned: in 2019 - 265 cases were reported (incidence $0.69 / 100,000$ ), while in $2020-158$ cases $(0.41 / 100,000){ }^{4}$

Analogic situation was stated after analysis of patient data from Department of Infectious Diseases and Neuroinfections, Medical University of Bialystok, Poland which for years has been diagnosing and treating patients with tick-borne diseases.

www.ecdc.com

Lyme disease: Global Status, GIDEON - Global Infectious Diseases and Epidemiology Online Network [dostęp 2020-08-07

Yijun Lou, Jianhong Wu, Modeling Lyme disease transmission, „Infectious Disease Modelling”, 2 (2), 2017, 229-243.

4 www.pzh.gov.pl
Od lat choroby przenoszone przez kleszcze stanowiły i stanowią ważny problem epidemiologiczny i kliniczny. Do najczęstszych i najlepiej poznanych chorób należy borelioza z Lyme oraz kleszczowe zapalenie mózgu (KZM).

Roczna liczba zachorowań na KZM w Europie od lat utrzymuje się na poziomie od 3000-4000 przypadków: 2006 - 3776, 2009-3513, 2010-4049, 2019 - 4049, zaś w Polsce notuje się od 200-300 zachorowań/rok (1).

Podobnie zapadalność na boreliozę z Lyme w Europie Zachodniej została oszacowana na 22,05 na 100 000 na rok (2). Całkowita liczba przypadków (zgłaszanych i niezgłaszanych) może wynosić ponad 200 000 rocznie (3). W Polsce od kilku ostatnich lat raportowano ok. 20000 zachorowań.

Wraz z nadejściem COVID-19 zmieniła się organizacja służby zdrowia w Polsce. Pandemia wymusiła przekształcanie oddziałów zakaźnych na oddziały zajmujące się wyłącznie leczeniem COVID-19. Zrodziło się więc pytanie, czy COVID-19 i obecna sytuacja wpłynęły na zapadalność na choroby odkleszczowe, w tym przede wszystkim na boreliozę i KZM.

Zgodnie z danymi opublikowanymi przez NIZP - PZH w 2019 roku w Polsce zanotowano 20630 przypadków boreliozy (zapadalność - 53,74/100 000), a tym 294 neuroboreliozy $(0,77 / 100$ 000), zaś w roku 2020 zanotowano 12524 przypadków boreliozy (zapadalność - 32,63/100 000), a tym 104 neuroboreliozy $(0,27 / 100000)$.

Podobną tendencję obserwowano w przypadku liczby zachorowań na KZM: w 2019 roku zanotowano 265 zachorowań (zapadalność - 0,69/100 000), zaś w 2020 - 158 (zapadalność - 0,41/100 000) (4).

Analogiczną sytuację stwierdzono analizując dane pacjentów Kliniki Chorób Zakaźnych i Neuroinfekcji Uniwersytetu Medycznego w Białymstoku, która od lat zajmuje się diagnostyką i leczeniem pacjentów $\mathrm{z}$ chorobami odkleszczowymi.

W przyklinicznej Poradni Antropozoonoz liczba pierwszorazowych wizyt pacjentów $\mathrm{z}$ boreliozą

(C) National Institute of Public Health - National Institute of Hygiene / Narodowy Instytut Zdrowia Publicznego - Państwowy Zakład Higieny 
In the outpatient department the numer of first time visits of patients with LD in 2019 was 290, while in 2020 - 45 (decrease for $84.5 \%$ ).

In the Department hundreds of patients with various symptoms ater tick bite were consulted. The symptoms included skin lesions, joint swelling, facial nerve pareses, brachial plexus pareses, headache, lumbosacral pain, fever, nausea, vomits, consciousness disturbances.Finaly these patients were hospitalized in internal medicine or neurological wards.

We analyzed the potential causes of such significant decrease in reported cases of tick borne diseases. The most common include:

- Low availability of healt care to patients with other than SARS-CoV-2 infection diseases

- The neccessity of SARS-CoV-2 testiong before hospitalization

- Fear of being infected with SARS-CoV-2 in the process of diagnostics and treatment of other diseases

- Lock-down which lowered the exposure to tick bites

- Hospitalization at wards with difficulty in access to LD and other tick borne diseases disgnostics

- Bad reporting of tick-borne diseases

All of these factors influencing on tick-borne diseases incidence are in accordance to observations made by Wormser et al. in USA. The Authors described 3 adult patients, in whom the diagnosis of tick-borne disease was delayed because of COVID-19 pandemics. ${ }^{5}$

To sum up it has to be emphasized that appearance of COVID-19 did not cause other diseases, including infectious diseases, to dissapear. They should be diagnosed and treated as soon as possible to prevent sequelae.

\section{REFERENCES}

1. Tick-borne encephalitis http://www.ecdc.com

2. Lyme disease: Global Status, GIDEON - Global Infectious Diseases and Epidemiology Online Network [dostęp 2021-02-07]

3. Lou $\mathrm{Y}, \mathrm{Wu}$ J. Modeling Lyme disease transmission. Infectious Disease Modelling 2017; 2 (2): 229-243.

4. Meldunki epidemiologiczne http://www.pzh.gov.pl

5. Wormser GP, Jacobson E, Shanker EM. Negative impact of the COVID-19 pandemic on the timely diagnosis of tick-borne infections. Diagn Microbiol Infect Dis 2021 Jan;99(1):115226.

\footnotetext{
Wormser GP, Jacobson E, Shanker EM. Negative impact of the COVID-19 pandemic on the timely diagnosis of tick-borne infections. Diagn Microbiol Infect Dis. 2021 Jan;99(1):115226. doi: 10.1016/j. diagmicrobio.2020.115226.
}

z Lyme w 2019 roku wyniosła - 290, zaś w 2020 - 45 (spadek o 84,5\%).

W Klinice konsultowano setki pacjentów z różnymi dolegliwościami po pokłuciu przez kleszcze: zmianami skórnymi, obrzękami stawów, porażeniem nerwów twarzowych, porażeniem splotu barkowego, bólami głowy, bólami odcinka L/S kręgosłupa, gorączką, nudnościami, wymiotami, zaburzeniami świadomości i innymi. Finalnie pacjenci ci byli hospitalizowani w oddziałach internistycznych lub neurologicznych.

Analizowano również potencjalne przyczyny spadku liczby raportowanych zachorowań na choroby przenoszone przez kleszcze. Do najczęstszych można zaliczyć:

- Trudności z dostępem do opieki medycznej chorych $\mathrm{z}$ innymi dolegliwościami niż wynikające z zakażenia SARS-CoV-2

- Konieczność testowania w kierunku zakażenia wirusem SARS-CoV-2 przed hospitalizacją

- Strach przed zakażeniem wirusem SARS-CoV-2 podczas diagnostyki i leczenia innych chorób

- Lock-down wpływający na zmniejszenie ekspozycji na pokłucie przez kleszcze

- Hospitalizacje w Oddziałach, które mają utrudniony dostęp do diagnostyki boreliozy i innych chorób przenoszonych przez kleszcze

- Niekompletna zgłaszalność w związku ze zwiększonym obciążeniem służby zdrowia

Te wszystkie czynniki wpływające na zapadalność na choroby odkleszczowe są zgodne z obserwacjami poczynionymi w USA przez Wormser i wsp., którzy opisali 3 dorosłych pacjentów, którzy wskutek trudności z dostępem do diagnostyki w erze COVID-19 mieli opóźnioną diagnozę choroby odkleszczowej (5).

Reasumując, należy zwrócić uwagę, iż wraz z pojawieniem się COVID-19 inne choroby, w tym choroby zakaźne nie zniknęły i nadal powinny być diagnozowane i leczone, jak najszybciej, by zapobiec odległym powikłaniom pochorobowym.

Received: 9.02.2021

Accepted for publication: 11.02.2021

Otrzymano: 9.02.2021 r.

Zaakceptowano do publikacji: 11.02.2021 r.

\section{Address for correspondence: Adres do korespondencji:}

Anna Moniuszko-Malinowska

Klinika Chorób Zakaźnych i Neuroinfekcji

Żurawia 14, 15-540 Białystok

Blok D

e-mail: annamoniuszko@op.pl 